\title{
The Estimation of the Willingness to Pay for Air-Quality Improvement in Thailand
}

\author{
Waranan Tantiwat ${ }^{1, *(\mathbb{D},}$, Christopher Gan ${ }^{1}\left(\mathbb{D}\right.$ and Wei Yang ${ }^{2}(\mathbb{D}$ \\ 1 Department of Financial and Business Systems, Faculty of Agribusiness and Commerce, Lincoln University, \\ Lincoln 7647, New Zealand; christopher.gan@lincoln.ac.nz \\ 2 Department of Global Value Chains and Trade, Faculty of Agribusiness and Commerce, Lincoln University, \\ Lincoln 7647, New Zealand; wei.yang@lincoln.ac.nz \\ * Correspondence: waranan.tantiwat@lincolnuni.ac.nz
}

check for

updates

Citation: Tantiwat, W.; Gan, C.; Yang, W. The Estimation of the Willingness to Pay for Air-Quality Improvement in Thailand. Sustainability 2021, 13, 12313. https://doi.org/10.3390/ su132112313

Academic Editor: Antonio Boggia

Received: 24 September 2021

Accepted: 2 November 2021

Published: 8 November 2021

Publisher's Note: MDPI stays neutral with regard to jurisdictional claims in published maps and institutional affiliations.

Copyright: (c) 2021 by the authors. Licensee MDPI, Basel, Switzerland. This article is an open access article distributed under the terms and conditions of the Creative Commons Attribution (CC BY) license (https:/ / creativecommons.org/licenses/by/ $4.0 /)$.

\begin{abstract}
Thailand has experienced severe air-quality problems for the past 10 years. Complicating this situation, the Thai government allocates an insufficient budget for the management of air pollution. Using the contingent valuation method, this paper estimates the willingness to pay for airquality improvement in Thailand to reveal the benefits that people will gain if air-quality improves. The results show that the total benefits from air-quality improvement would be 18.8 billion baht in 2020. The Thai government can use these findings as a guideline to redistribute its budget to address air pollution more effectively.
\end{abstract}

Keywords: willingness to pay; air quality improvement; contingent valuation method; Thailand

\section{Introduction}

Along with economic growth, an increase in consumption and production activities leads to lethal consequences from polluted air; air pollution is a negative externality of consumption and production [1]. Currently, air quality has become a critical environmental problem and a persistent concern in many cities in developing countries [2,3]. Thailand, an upper middle-income country, has experienced severe air-quality problems for the past decade [4-6]. Based on statistics from the World Health Organization (WHO) ambient air pollution database (the air pollution is indicated by the annual concentrations of $\mathrm{PM}_{2.5}$ level.), Bangkok, Thailand, is ranked 9th among the 32 cities with the highest particulate matter $(\mathrm{PM})_{2.5}$ levels around the world [7]. Currently, Bangkok's air pollution exceeds WHO standards for several pollutants: nitrogen dioxide $\left(\mathrm{NO}_{2}\right)$, ground-level ozone $\left(\mathrm{O}_{3}\right)$, and particulate matter that have a diameter of less than 2.5 and $10 \mu \mathrm{m}\left(\mathrm{PM}_{2.5}\right.$, and $\left.\mathrm{PM}_{10}\right)$ [8]. The main source of ambient air pollution in Bangkok is road transport; the number of road vehicles in Bangkok increased by 54\% from 2008 to 2020 [9].

Air pollution in Thailand is responsible for 50,000 deaths every year. This is a public health crisis in which children, the elderly and the most vulnerable people are most exposed to toxic air [10]. The number of patients with respiratory disease, cardiovascular, and lung diseases in Thailand from 2007 to 2018 increased by 50\%, 62\% and 97\%, respectively [11]. However, the budget for the management of pollution and the environment between 2007 and 2018 was small (4636 million baht in 2007 and 12,917 million baht in 2018), an average of $0.36 \%$ (range $0.28-0.48 \%$ ) of the total government budget. This is a very small budget, leading to ineffective solutions for the air pollution problem [6]. The Thai government is faced with difficult choices in its budget allocation to support economic growth while balancing the need to reduce the impact of growing prosperity [5]. The key challenge to resolve the air-quality problem in Thailand critically depends on the coherent integration by the Thai government of social concerns with scientifically sound technology, coupled with a deep understanding of the problem and the benefits realized from its resolution. 
Without such a deep understanding, insufficient funds are being allocated to deal with air pollution and the air-quality problems have not been resolved. One possible reason is that the Thai government has not estimated the total benefit that people will gain if air quality is improved. The total benefit in this study is estimated from the amount of money that people are willing to pay to improve air quality. According to Wangwongwattana [12], air-quality improvement leads to many economic benefits including an increase in gross national income per capita and a reduction in the costs of illnesses (e.g., hospital charges and lost wages for parents who stay home to care for a sick child). Wangwongwattana's study also reported that improving air quality by reducing $\mathrm{PM}_{2.5}$ could lessen mortality by up to 120 people in 2035. Additionally, the valuation of health benefits from air-quality improvement is $0.2-0.3$ billion USD because of reduced mortality in 2035. In contrast, if the air pollution situation persists, it will generate other economic costs such as increased medical expenses and loss of tourism revenue. This paper evaluates the willingness to pay (WTP) to improve air quality in Thailand. The WTP value to improve air quality reflects the total benefit that people will gain if air quality is improved. The Thai government can use this study's findings as a guideline when allocating the budget to deal with air pollution.

\section{Literature Review}

The contingent valuation method (CVM) is a well-known "stated preference" approach to estimate the WTP for non-market goods. CVM is a useful technique to deal with non-market goods, because it can provide a monetary value for an intangible good that does not have a market price [13]. This method, based on a survey, directly asks people about their willingness to pay for public goods such as environmental and natural resources $[14,15]$.

Many CVM studies estimate the benefits of air-quality improvement in monetary terms, focusing on a specific region, including Africa, Europe, North and South America and Asia [15-18] (see Table 1). For example, Donfouet, Cook and Jeanty [19] calculated households' WTP value for air-quality improvements in Douala, Cameroon. Households were asked how much they would be willing to pay for a $25 \%$ reduction in air pollution. The results show that the annual benefit of air-quality improvements was 749,064 USD per household. Likewise, Maloma and Sekatane [20] quantified an individual's WTP for improved air quality in Bophelong, South Africa, using CVM. The results showed that the WTP value to reduce air pollution was approximately 25 USD per annum. A study that estimated the WTP value for air-quality improvements in Nairobi, Kenya also used CVM to calculate WTP by asking the respondents the highest amount they would be willing to pay for motorized emission reductions. The results show the WTP value for air-quality improvements in Nairobi, Kenya, at 4.67 USD per person per month [21].

In European countries, Wang and Whittington [22] used CVM to measure the WTP for air-quality improvements in Sofia, Bulgaria. They found that people were willing to pay up to $4.7 \%$ of their income for a program to improve air quality. In the same year, Carlsson and Johansson-Stenman [23] estimated the WTP for improved air quality in Sweden. They asked respondents how much they would be willing to pay for a $50 \%$ reduction of harmful substances in the air. Their results revealed the WTP for a $50 \%$ reduction of harmful substances around homes and workplaces was about 2000 SEK per year. Some other studies in Europe have also used the CVM method to estimate WTP to avoid health risks from road transport-related air pollution. For instance, Alberini and Chiabai [24] used CVM to elicit WTP for a reduction in the risk of dying from cardiovascular and respiratory diseases from air pollution among Italian people. They found the WTP was at least 950 euros per year for the health risk reduction. Vlachokostas et al. [25] assessed the WTP to reduce the risk of premature mortality attributable to air pollution in Thessaloniki, Greece. The results revealed that the WTP to save 1 year of life loss was approximately 920 euros per person per year. This WTP value was relatively close to the WTP value in the study [24]. 
Table 1. A summary of the literature review.

\begin{tabular}{|c|c|}
\hline Author(s) & Study Aim \\
\hline \multicolumn{2}{|r|}{ Africa } \\
\hline $\begin{array}{c}\text { Donfouet, Cook and Jeanty [19] } \\
\text { Maloma and Sekatane [20] } \\
\text { Ndambiri, Mungatana and Brouwer [21] }\end{array}$ & To estimate the benefits of air-quality improvement \\
\hline \multicolumn{2}{|r|}{ Europe } \\
\hline $\begin{array}{c}\text { Wang and Whittington [22] } \\
\text { Carlsson and Johansson-Stenman [23] } \\
\text { Alberini and Chiabai [24] } \\
\text { Vlachokostas et al. [25] } \\
\text { Dziegielewska and Mendelsohn [26] } \\
\text { Ligus [27] } \\
\text { Lera-López, Sánchez, Faulin, and Cacciolatti [28] }\end{array}$ & $\begin{array}{l}\text { To estimate the benefits of air-quality improvement } \\
\text { To estimate people's willingness to pay (WTP) to avoid health risks from } \\
\text { road transport related air pollution } \\
\text { To evaluate the economic damages due to air pollution caused by transport }\end{array}$ \\
\hline \multicolumn{2}{|c|}{ North and South America } \\
\hline $\begin{array}{l}\text { Poder and He [29] } \\
\text { Filippini and Martínez-Cruz [30] }\end{array}$ & $\begin{array}{c}\text { To calculate WTP for cleaner cars in Canada } \\
\text { To evaluate WTP to reduce air pollution }\end{array}$ \\
\hline \multicolumn{2}{|r|}{ Asia } \\
\hline $\begin{array}{c}\text { Firooz Zare and Ghorbani [31] } \\
\text { Akhtar, Saleem, Nadeem, Shahid and Ikram [32] }\end{array}$ & To estimate the benefits of air-quality improvement \\
\hline Lee et al. [33] & $\begin{array}{l}\text { To evaluate WTP for reducing the mortality rate associated } \\
\text { with vehicle emissions }\end{array}$ \\
\hline $\begin{array}{c}\text { Wang et al. [34] } \\
\text { Chen et al. [35] } \\
\text { Wei and Wu [36] } \\
\text { Liu et al. }\end{array}$ & To estimate the benefits of air-quality improvement \\
\hline $\begin{array}{l}\text { Masahina, Afroz, Duasa and Mohamed [37] } \\
\text { Bazrbachi et al. [38] }\end{array}$ & To estimate the WTP to resolve the air-quality problem caused by transport \\
\hline \multicolumn{2}{|r|}{ Thailand } \\
\hline Vassanadumrongdee and Matsuoka [39] & To measure the economic costs of mortality from air pollution. \\
\hline Attavanich [5] & $\begin{array}{l}\text { To evaluate the environmental cost from the First-Time Car Buyer Program } \\
\text { in Bangkok, Thailand. }\end{array}$ \\
\hline
\end{tabular}

Various studies in Europe have evaluated the economic damage because of air pollution caused by transport. Like other studies on air-quality improvement and health risks from air pollution in European countries, CVM was used to elicit the WTP for clean air in these studies. For example, Dziegielewska and Mendelsohn [26] estimated all damage components of air pollution in Poland. The damage components from air pollution are mortality, bronchitis, asthma, minor health effects, material damage, and damage to historical heritage and ecosystems. The authors asked how much Polish citizens would be willing to pay to align Polish air pollution standards with the EU standards. Their results show that the WTP value was about 1\% of GDP per capita in 2004 [26]. In another Polish study, Ligus [27] calculated the WTP for improved air quality by asking people about how much they would be willing to pay for clean air, The results showed that Polish people were willing to pay 21,172 PLN per month for clean air. Additionally, Lera-López, Sánchez, Faulin, and Cacciolatti [28] used CVM to measure the impact of road transport externalities in the Western Pyrenees mountains. They evaluated the WTP to reduce air pollution caused by road transport. Their results show households living near main roads experienced welfare losses of around 45 euros per household per year.

In North America, Poder and He [29] used CVM to calculate WTP for cleaner cars in Canada. The study asked Canadians how much more they are likely to pay for cleaner vehicles to reduce air pollution. The results showed that people were willing to pay an extra 3000 to 8000 CAD to buy cleaner vehicles. A study in South America used CVM to evaluate 
WTP to reduce air pollution. Filippini and Martínez-Cruz [30] used CVM to estimate the environmental impacts of transport in Mexico City by asking the respondents about their WTP to reduce air pollution. The authors found the welfare loss was approximately 262 USD per person per year.

In Asian countries, Firooz Zare and Ghorbani [31] investigated public preferences for improving air pollution in Mashhad, Iran, by estimating WTP for a $30 \%$ improvement in air quality. The authors applied CVM to estimate the WTP for an improvement in air quality. Their results showed that the WTP value for a $30 \%$ improvement in air quality equals 12,376,575,510 IRR per month. In the same year, Lee et al. [32] used CVM to evaluate WTP to reduce mortality associated with vehicle emissions. The estimated damage costs because of the risks from $\mathrm{PM}_{2.5}$ inhalation in Seoul is about 1057 million USD per year. In addition, [33] applied CVM to assess the WTP for improved air quality in Pakistan. Respondents were asked how much they would be willing to pay to decrease the level of air contamination by $50 \%$. The results showed that the WTP for improved air quality was 9.86 USD per month per person.

Most studies in China use CVM to elicit WTP for air-quality improvement. For instance, [3] used the CVM method to estimate Shanghai residents' WTP to reduce air pollution to improve children's health. They asked the respondents how much they were willing to pay to keep children from suffering respiratory diseases. The results indicated that the WTP to reduce children's respiratory diseases through air-quality improvement was 80.7 USD annually. Similarly, [34] quantified the public health benefits of $\mathrm{PM}_{2.5}$ mitigation in the Beijing-Tianjin-Hebei region, China. Respondents were asked how much they were willing to pay to avoid cardiovascular mortality, respiratory mortality, and lung cancer. The results showed that the WTP value to avoid cardiovascular mortality, respiratory mortality and lung cancer range from 637 to 13,325, 120 to 3579, and 1091 to 6574 million CNY, respectively. The overall WTP value to avoid causes of mortality in this study was from 1110 to 29,632 CNY. In the same year, [35] estimated the WTP to mitigate air pollution in the Jing-Jin-Ji region, China. The study asked respondents what was the maximum they would be willing to pay for an $80 \%$ reduction in the concentration of $\mathrm{PM}_{2.5}$. The findings revealed a WTP of 602 CNY per year, approximately 1\% of the GDP per capita. Similarly, [36] assessed the WTP for improved air quality among manufacturing workers in Nanchang, China. The workers were asked if they were willing to pay a certain amount of money every month to improve ambient air quality. The authors found that over $50 \%$ of manufacturing workers in Nanchang were willing to pay for improving air quality.

Several studies in Southeast Asia have estimated the WTP to resolve air-quality problems caused by transport. Most studies applied the CVM method to measure WTP to improve air quality. For example, [37] estimate the WTP to improve air quality in the Klang Valley, Malaysia, using the CVM method. They asked respondents their WTP to avoid illnesses because of air pollution. Similarly, another study [38] in the Klang Valley, Malaysia, also used CVM to estimate the WTP to improve air quality. They asked private vehicle users how much they would like to pay to continue using their private vehicle. The results showed that private passenger vehicle users are willing to pay a maximum amount of 1.55 USD per trip to continue using their private vehicle.

In Thailand, [39] applied CVM to measure the economic cost of mortality from air pollution. Participants were asked about their WTP to reduce the mortality risk arising from air pollution. Their findings revealed the economic costs of mortality from air pollution to be 0.74 to 1.32 million USD per year. A subjective well-being approach (SWB) was used to evaluate the environmental cost of the First-Time Car Buyer Program in Bangkok, Thailand. The results show the estimated total annual environmental cost from the program is 6.173 billion USD [5]. Noticeably, previous literature on Thailand focused on estimating the damage or cost of air pollution. There is no study on Thailand that uses the CVM to estimate the benefit that people will gain if air quality is improved. Thus, this study is the first attempt to use CVM to estimate the benefit of air-quality improvement in Thailand. 


\section{Methodology}

This study uses a quota sampling approach to collect data. Quota sampling can be considered a form of proportional stratified sampling, where a predetermined proportion of people is sampled from different groups, but on a convenience basis [40]. In our study, the number of people targeted in each of the 50 districts is proportional to the population density of that district (The total number of population divided by the total area). To select the respondents from the targeted people in each of the 50 districts, convenience sampling was used. Convenience sampling is the easiest way to reach respondents when the researcher wishes to describe a particular group. This sampling method focuses on the respondents' availability rather than selection from the entire population [40]. Thus, we used convenience sampling to survey people who were $\geq 18$ years old, currently residing in Bangkok. Eight hundred questionnaires were distributed throughout Bangkok from June to October 2020 in public places such as malls and public parks. Additionally, online, mobile phone and face time/VDO call surveys were used in this study because of COVID-19 restrictions in Thailand. The surveys resulted in 642 questionnaires returned, with 602 useable ones (response rate $80 \%$ ).

We applied the double-bounded contingent valuation method to estimate the WTP for improving air quality. The double-bounded discrete choice format is more informationintensive and achieves more statistical efficiency than the single-bounded discrete choice format [41,42]. The double-bounded dichotomous choice is asymptotically more efficient than the single-bounded model [43]. Moreover, [42] reveal that the double-bounded discrete choice format offers greater precision for coefficient estimates (i.e., the mean and median WTP) and lower mean squared error. These results lead to tighter confidence intervals around the WTP estimates. Reference [44] explain that adding one or more additional follow-up questions improves estimation efficiency. In addition, the doublebounded discrete choice format avoids starting point bias as this format has only one follow-up question, unlike the bidding game format. Thus, respondents are not exhausted by responding to questions. The anchoring problem can be avoided as the magnitudes of the first and second bids are very different. The response in the second bid is bounded by a higher value than the first bid. Therefore, the yea-saying problem in the second bid is less likely to occur [45]. Like the findings of [44], they also found that the double-bounded discrete choice format can solve problems of starting point bias, anchoring effect and yea-saying that have been the main criticisms of the CVM approach [44]. Likewise, [46] indicate that responses to subsequent valuation questions in double-bounded elicitation questions do not affect the incentive compatibility of the initial question. In other words, the double-bounded elicitation question does not violate incentive compatibility [46].

In practice, the double-bounded discrete choice format in CVM is more extensively used to elicit people's WTP for environmental goods and services [47]. The National Oceanic and Atmospheric Administration (NOAA) suggests the double-bounded discrete choices format be recommended over other elicitation formats for estimating WTP. This format can better capture the thoughts of respondents' than open-ended and bidding game formats. References $[33,48,49]$ show that the use of a single or double bounded discrete choice is preferred for evaluating public goods, given the established incentive properties of these formats. Similarly, [50] support single and double bounded discrete choices as incentive compatible for public goods.

This study offered the respondents four ranges of starting bids to guard against starting point bias. The difference between each initial bid value can be adjusted to provide a wide interval of WTP. As a result, the estimated WTP value is more precise. Using four starting bids created in the bid design, this study provides four versions of the survey questionnaire (versions A, B, C, and D) (see Table 2); each version has a different starting bid. 
Table 2. Dichotomous choice survey questionnaire to elicit people's willingness to pay (WTP) for air-quality improvement.

\begin{tabular}{cccc}
\hline \multirow{2}{*}{$\begin{array}{c}\text { Survey Questionnaire } \\
\text { Version }\end{array}$} & $\begin{array}{c}\text { First Bid } \\
\text { (Baht per Year) }\end{array}$ & Lower Amount & Higher Amount \\
\cline { 3 - 4 } & 500 & 250 & 1000 \\
A & 1000 & 500 & 2000 \\
B & 2000 & 1000 & 4000 \\
D & 4000 & 2000 & 8000 \\
\hline
\end{tabular}

We also compare two elicitation question formats of CVM: Model 1: the doublebounded dichotomous choice format; and Model 2: the double-bounded dichotomous choice format followed by open-ended direct elicitation format to improve the statistical efficiency of the WTP estimates. Based on the economic theory of the double-bounded discrete choice format, respondents were asked about their WTP for air-quality improvement with the first and second bids of the dichotomous choice question. In Model 1, the double-bounded dichotomous choice format was applied to provide the lower and upper bounds of WTP values. The upper bound in the highest range of the interval-censoring model is infinity $(+\infty)$ and the lower bound in the lower range (No/No answer) equals zero because there is no market price, and no monetary value for air. In Model 2, after respondents answer the double-bounded discrete choice question they are asked an openended elicitation question to specify their maximum WTP for air-quality improvement (see Figure 1). In other words, Model 2 uses an open-ended question approach to provide the bounds of WTP values as the minimum and maximum bounds of WTP values. Therefore, the highest amount of the respondents' true WTP received from the open ended direct question is what each respondent provides as the maximum WTP value (see Table 3). It is assumed that respondents' WTP would consider the income constraint that is consistent with economic theory. This method should provide more reliable and reasonable WTP estimates [51].

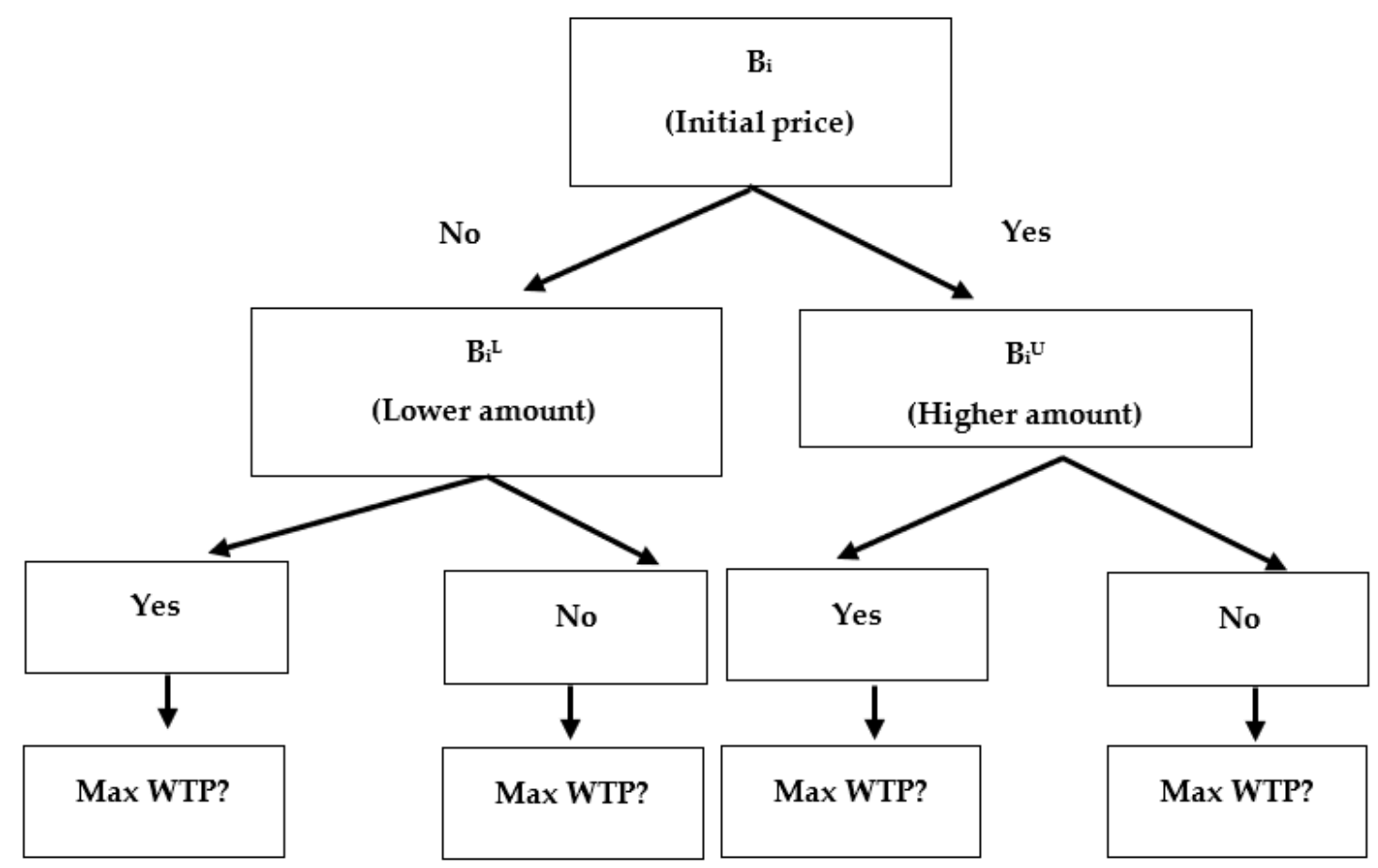

First bid

(Initial price)

Second bid/

(Follow-up prices)

Open-ended

question

Figure 1. The bidding sequence for the double-bounded discrete choice format. 
Table 3. WTP ranges of the double-bounded discrete choice format.

\begin{tabular}{ccccc}
\hline \multirow{2}{*}{$\begin{array}{c}\text { Possible Answer } \\
\text { (First Bid/Second Bid) }\end{array}$} & \multicolumn{2}{c}{$\begin{array}{c}\text { Model 1 } \\
\text { (Lower, Upper) }\end{array}$} & \multicolumn{2}{c}{$\begin{array}{c}\text { Model 2 } \\
\text { (Min, Max) }\end{array}$} \\
\cline { 2 - 5 } & Lower Bound & Upper Bound & Lower Bound & Upper Bound \\
\hline Yes/Yes & $\mathrm{B}_{\mathrm{i}}^{\mathrm{U}}$ & $\infty$ & $\mathrm{B}_{\mathrm{i}}{ }^{\mathrm{U}}$ & $\mathrm{Max}$ \\
Yes/No & $\mathrm{B}_{\mathrm{i}}$ & $\mathrm{B}_{\mathrm{i}}^{\mathrm{L}}$ & $\mathrm{B}_{\mathrm{i}}$ & $\mathrm{B}_{\mathrm{i}}^{\mathrm{U}}$ \\
No/Yes & $\mathrm{B}_{\mathrm{i}}^{\mathrm{L}}$ & $\mathrm{B}_{\mathrm{i}}$ & $\mathrm{B}_{\mathrm{i}}^{\mathrm{L}}$ & $\mathrm{B}_{\mathrm{i}}$ \\
No/No & 0 & $\mathrm{~B}_{\mathrm{i}}$ & 0 & $\mathrm{~B}_{\mathrm{i}}$ \\
\hline
\end{tabular}

"Yes/Yes" means Yes responses in the starting and Yes responses in the following bid. "Yes/No" means Yes responses in the starting and No responses in the following bid. "No/Yes" means No responses in the starting and Yes responses in the following bid. "No/No" means No responses in the starting and No responses in the following bid. $\mathrm{B}_{\mathrm{i}}^{\mathrm{U}}=$ Second bid (Higher amount); $\mathrm{B}_{\mathrm{i}}^{\mathrm{L}}=$ Second bid (Lower amount); $\mathrm{B}_{\mathrm{i}}=$ First bid.

Table 3 shows four different possible answers for the respondents' WTP for air-quality improvement. This means the double-bounded CVM does not provide the true measure of maximum WTP to improve air quality, rather it provides a set of bounds as interval censored data. The benefit of the double-bounded discrete choices format is that this format leads to tighter confidence intervals around the WTP estimates. According to previous studies, such as [42,47], the WTP value estimated from double bounded discrete choices was significantly larger than those obtained from other question formats. Similarly, [29] find that information obtained from the double-bounded discrete choices format was more reliable than other question formats. These answers were coded as binary-value variables. Therefore, the WTP value to improve air quality is bounded between minimum and maximum values of the four possible answers. The literature shows that the determinants of WTP to improve air quality include socio-demographic characteristics, living area and environment, personal lifestyle, knowledge about air pollution, awareness of air pollution, attitudes towards air pollution, and attitudes towards air-quality policies $[37,38,52]$ (see Table 4). The WTP model for air-quality improvement is specified in Equations (1) and (2).

Model 1 (Equation (1)) is estimated by a censored regression model. The censored regression model is a model in which the dependent variable is censored (in statistics, censoring is the condition where the value of a measurement or observation is only partially known) above or below a certain threshold. This model is used for data where the value for only the dependent variable is unknown; the values of the independent variables are available. In this context, the double-bounded dichotomous choice format provides the lower and upper bounds of WTP values (the dependent variables). The lower bound in the lower range (No/No answer) equals zero because there is no market price and no monetary value for air. However, the upper bound in the highest range (Yes/Yes answer) cannot reveal the exact monetary value. Thus, the censored regression model is well suited to conceptualise and estimate WTP values based on the double bounded dichotomous choice format. The upper bound in the highest range of the interval-censoring model is infinity $(+\infty)$.

Model 2 (Equation (2)) uses the double-bounded discrete choice format combined with the additional open-ended elicitation questions to estimate the WTP for air-quality improvement. Model 2 is also estimated by a censored regression model. This model uses the truncation approach for the upper bound values with regard to the maximum WTP obtained from the open-ended question. The truncation approach provides more reliable and reasonable WTP estimates. Thus, in this model, the upper bound values were truncated to the highest interval range (Yes/Yes answer) to estimate WTP [49]. The highest WTP of the respondents obtained from the open-ended question is selected to indicate the upper bound of the highest interval range (Max) (Model 2). Table 3 presents the factors that affect people's WTP to improve air quality in this study. 
Table 4. The determinants of the WTP to improve air quality in Thailand.

\begin{tabular}{|c|c|}
\hline Variable & Description \\
\hline & Dependent variable (Model 1) \\
\hline Lower & The lowest value that the respondents are willing to pay for improving air quality (numeric) \\
\hline Upper & $\begin{array}{c}\text { The highest value that the respondents are willing to pay improving air quality (numeric) } \\
\text { Dependent variable (Model 2) }\end{array}$ \\
\hline Min & The minimum value that the respondents are willing to pay for improving air quality (numeric) \\
\hline Max & $\begin{array}{l}\text { The maximum value that the respondents are willing to pay improving air quality (numeric) } \\
\text { Independent variables }\end{array}$ \\
\hline Gender & $1=$ if respondent is male; $0=$ female \\
\hline Age1 & $1=$ if respondent is less than or equal to 25 years old; $0=$ otherwise \\
\hline Age2 & $1=$ if respondent is between 26 and 35 years old; $0=$ otherwise \\
\hline Age3 & $1=$ if respondent is between 36 and 45 years old; $0=$ otherwise \\
\hline Age4 & $1=$ if respondent is between 46 and 55 years old; $0=$ otherwise \\
\hline Age5 * & $1=$ if respondent is between 56 and 65 years old; $0=$ otherwise \\
\hline Sta & $1=$ if respondent is single divorced and widowed; $0=$ married \\
\hline Edu & The respondent highest educational qualification (numeric) \\
\hline Occ1 & $1=$ if respondent is government officer; $0=$ otherwise \\
\hline Occ2 & $1=$ if respondent is student; $0=$ otherwise \\
\hline Occ3 & $1=$ if respondent is private company officer; $0=$ otherwise \\
\hline Occ4 & $1=$ if respondent is self-employed; $0=$ otherwise \\
\hline Occ5 & $1=$ if respondent is farmer; $0=$ otherwise \\
\hline Occ6 & $1=$ if respondent is labourer; $0=$ otherwise \\
\hline $\mathrm{Occ} 7 *$ & $1=$ if respondent is unemployed, retired, and housewife $/$ husband); $0=$ otherwise \\
\hline Mem1 & The number of household members aged less than 7 years old (numeric) \\
\hline Mem2 & The number of household members aged between 8 and 17 years old (numeric) \\
\hline Mem3 & The number of household members aged between 18 and 59 years old (numeric) \\
\hline Mem4 & The number of household members aged 60 years old and older (numeric) \\
\hline IncEarn & The number of income earners in the respondent's household (numeric) \\
\hline Inc1 & $1=$ if respondent has income Less than 30,000 baht; $0=$ otherwise \\
\hline Inc2 & $1=$ if respondent has income between 30,001 and 45,000 baht; $0=$ otherwise \\
\hline Inc3 & $1=$ if respondent has income between 45,001 and 60,000 baht; $0=$ otherwise \\
\hline Inc4 & $1=$ if respondent has income between 60,001 and 75,000 baht; $0=$ otherwise \\
\hline Inc5 & $1=$ if respondent has income between 75,001 and 90,000 baht; $0=$ otherwise \\
\hline Inc6 & $1=$ if respondent has income between 90,001 and 105,000 baht; $0=$ otherwise \\
\hline Inc7 & $1=$ if respondent has income between 105,001 and 120,000 baht; $0=$ otherwise \\
\hline Inc8 & $1=$ if respondent has income between 120,001 and 135,000 baht; $0=$ otherwise \\
\hline Inc9 * & $1=$ if respondent has income over $135,001 \mathrm{baht} ; 0=$ otherwise \\
\hline SickLastTwo & $1=$ if respondent had respiratory illnesses in last 2 years; $0=$ otherwise \\
\hline APZone & $\begin{array}{c}1=\text { if respondent resides in the district that the level of } \mathrm{PM}_{2.5} \text { is over Thailand's national ambient air-quality } \\
\text { standards; } 0=\text { otherwise }\end{array}$ \\
\hline CZone & $1=$ if respondent resides in the district that has the greater traffic congestion level; $0=$ otherwise \\
\hline Area & $1=$ if respondent resides in the urban area; $0=$ otherwise \\
\hline Act & $1=$ if respondent prefers indoor activities; $0=$ outdoor activities \\
\hline Donate & $1=$ if respondent donates to environmental groups or organisations; $0=$ otherwise \\
\hline Knowledge & Knowledge regarding air pollution (summated scale) \\
\hline Aware & The awareness about air pollution (summated scale) \\
\hline Atti & Attitudes toward air pollution (summated scale) \\
\hline Think & Attitudes toward the use of road transportation and air-quality problems (summated scale) \\
\hline GAtti & Attitudes toward air-quality policies (summated scale) \\
\hline
\end{tabular}

* indicates the base group, removed from the models to avoid perfect collinearity. 
Model 1:

[Lower, Upper] $=\mathrm{f}($ Gender, Age1, Age2, Age3, Age4, Age5, Sta, EDU, Occ1, Occ2, Occ3, Occ4, Occ5, Occ6, Occ7, Mem1, Mem2, Mem3, Mem4, IncEarn, Inc1, Inc2, Inc3, Inc4, Inc5, Inc6, Inc7, Inc8, Inc9, SickLastTwo, APZone, CZone, Area, Act, Donate, Knowledge about air pollution, Awareness about air pollution, Attitudes toward air pollution, and Attitudes toward air quality policies)

Model 2:

[Min, Max] = f(Gender, Age1, Age2, Age3, Age4, Age5, Sta, EDU, Occ1, Occ2, Occ3, Occ4, Occ5, Occ6, Occ7, Mem1, Mem2, Mem3, Mem4, IncEarn, Inc1, Inc2, Inc3, Inc4, Inc5, Inc6, Inc7, Inc8, Inc9, SickLastTwo, APZone, CZone, Area, Act, Donate, Knowledge about air pollution, Awareness about air pollution, Attitudes toward air pollution, and Attitudes toward air quality policies)

Using the double-bounded CVM, the probability distribution that fits the log-likelihood function is limited to a non-negative distribution: log-normal, log-logistic, and Weibull. This restriction is required because the possible WTP values for air-quality improvement are positive $(0,+\infty)$ [14]. To choose the appropriate probability distribution with the WTP data, the value of the log-likelihood function in the restricted model leaves only the constant and bid terms to be used [14]. The mean and median WTP values can be estimated by the following three formulae (see Table 5) [14]. The mean and median WTP values can be computed using the estimated parameters from the constant-only bid function, which restricts all the independent variables except for the bid variable. Therefore, estimation of the parameters is contained in the constant (intercept: $\alpha$ ) and bid variable (scale: $\sigma$ ) of the model.

Table 5. Formulas to calculate the mean and median WTP values.

\begin{tabular}{ccc}
\hline Distribution & Mean WTP & Median WTP \\
\hline Log-normal & $\mathrm{e}^{\alpha+0.5 \sigma 2}$ & $\mathrm{e}^{\alpha}$ \\
Log-logistic & $\mathrm{e}^{-\alpha / \beta} \frac{\pi / \beta}{\sin -\pi / \beta}$ & $\mathrm{e}-\alpha / \beta$ \\
Weibull & $\mathrm{e}^{\alpha} \tau 1+\sigma$ & $\mathrm{e}^{\alpha} \ln 2 \sigma$ \\
\hline
\end{tabular}

\section{Results and Discussion}

The descriptive statistics for the respondents' profile show that the majority were women between 26 and 35 years old, single, had completed a bachelor's degree, and worked as a private company officer. The highest income per month was between 75,001 and 90,000 baht $(18 \%)$. For household composition and geography, the respondents were adults aged between 18 and 59 years old ( $88 \%$ ) and resided in the city $(54 \%)$ and in a congested zone (54\%). For air pollution areas, $13 \%$ of the respondents lived in air polluted areas. In addition, $83 \%$ of the respondents had had a respiratory illness in the last 2 years. The results show $60.96 \%$ of the respondents preferred indoor activities. Furthermore, $64 \%$ of the respondents donated money to environmental agencies.

The respondents were asked about their knowledge and understanding of air pollution. The survey results show that the respondents had a good knowledge of the health effects of air pollution. This may be influenced by the fact that the Thai government and hospitals provide this general type of information to the public. The mean score of the knowledge about the health effects of air pollution was 3.85 (on a scale of 1 to 5). The mean scores of the knowledge about environmental effects and prevention of air pollution were 3.80 and 3.78 (on a scale of 1 to 5), respectively (see Table 6). Respondents' attitudes toward air 
pollution show that they had the most concern about health. Most respondents strongly agreed "air pollution reduction is essential for people's health" (see Table 7).

Table 6. Respondents' knowledge level of air pollution.

\begin{tabular}{ccc}
\hline Air Pollution & \multicolumn{2}{c}{ Number of Responses (602 People) } \\
\cline { 2 - 3 } & Mean & SD \\
\hline Definition of air pollution & 3.60 & 0.82 \\
Identify types of air pollution & 3.34 & 1.03 \\
Causes of air pollution & 3.72 & 0.82 \\
Environmental effects of air pollution & 3.80 & 0.84 \\
Health effects of air pollution & 3.85 & 0.84 \\
Economic effects of air pollution & 3.45 & 1.07 \\
Thailand's national ambient air-quality standards & 2.89 & 1.35 \\
World Health Organization (WHO) & 2.58 & 1.53 \\
air-quality guidelines & 2.99 & 1.52 \\
Sources to receive information about air quality & 2.35 & 1.54 \\
Air quality index & 2.37 & 1.54 \\
Air quality health index & 2.73 & 1.49 \\
Air pollution forecast & 2.70 & 1.36 \\
The air-quality monitoring stations in Bangkok & 3.16 & 1.17 \\
Government policies to reduce air pollution & 3.78 & 0.93 \\
Prevention of air pollution & 5
\end{tabular}

Note: * The mean is computed from 1 for "Not at all knowledgeable" to 5 for "Very knowledgeable"; the mean scores exclude "don't know" or "not answered" responses.

Table 7. Respondents' attitudes toward air pollution.

\begin{tabular}{|c|c|c|}
\hline \multirow{2}{*}{ Statement } & \multicolumn{2}{|c|}{ Number of Responses (602 People) } \\
\hline & Mean * & SD \\
\hline $\begin{array}{l}\text { Solving air-quality issues should be one of the top three } \\
\text { priorities for public spending in Bangkok }\end{array}$ & 3.76 & 0.84 \\
\hline $\begin{array}{c}\text { It is important for everyone to give up some activities in } \\
\text { order to protect air quality }\end{array}$ & 3.83 & 0.78 \\
\hline $\begin{array}{l}\text { Air pollution is the most significant environmental issue } \\
\text { in Bangkok }\end{array}$ & 4.00 & 0.74 \\
\hline $\begin{array}{c}\text { The most important source of air pollution is } \\
\text { human activities }\end{array}$ & 4.16 & 0.83 \\
\hline The major source of air pollution in Bangkok is transport & 4.24 & 0.76 \\
\hline $\begin{array}{l}\text { Air pollution reduction is very important for } \\
\text { people's health }\end{array}$ & 4.28 & 0.77 \\
\hline $\begin{array}{c}\text { The historical air-quality index is useful to identify the } \\
\text { level of severe air pollution situation }\end{array}$ & 3.74 & 0.81 \\
\hline $\begin{array}{c}\text { The information about air pollution is important to } \\
\text { make people aware of air pollution }\end{array}$ & 3.82 & 0.85 \\
\hline It is not my responsibility to protect air quality & 2.46 & 1.16 \\
\hline $\begin{array}{c}\text { It is solely the government responsibility to solve } \\
\text { air-quality problems }\end{array}$ & 2.54 & 1.20 \\
\hline $\begin{array}{l}\text { It is the people responsibility to improve air quality } \\
\text { because everyone benefits }\end{array}$ & 3.92 & 0.99 \\
\hline $\begin{array}{c}\text { The level of taxes should affect the investment in air } \\
\text { pollution reduction }\end{array}$ & 2.96 & 0.94 \\
\hline $\begin{array}{c}\text { If I had a lot of money, I would like to pay more for } \\
\text { cleaner air }\end{array}$ & 3.02 & 0.91 \\
\hline $\begin{array}{l}\text { The developed countries should donate money to } \\
\text { reduce air pollution in Bangkok }\end{array}$ & 3.19 & 1.00 \\
\hline
\end{tabular}

Note: * The mean is computed from values of 5 for "Strongly agree" to 1 for "Strongly disagree"; the mean scores exclude "don't know" or "not answered" responses. 
With regard to concern about the health consequences of poor air quality, $61 \%$ of the respondents indicated that they are somewhat concerned followed by $31 \%$ who indicated that they are very concerned about the health consequences of air pollution. Only $8 \%$ of the respondents indicated that they are not sure or they are not concerned at all. The results imply that the majority of respondents are concerned about the health consequences of poor air quality (see Table 8).

Table 8. Respondents' concern level about air pollution in Bangkok.

\begin{tabular}{ccc}
\hline Concern Level & Number of Responses (Persons) & Percent \\
\hline Very concerned & 189 & 31.40 \\
Somewhat concerned & 366 & 60.80 \\
Not sure & 39 & 6.48 \\
Not concerned at all & 8 & 1.32 \\
\hline Total & 602 & 100.00 \\
\hline
\end{tabular}

With regard to respondents' perception of road transport use and air pollution (see Table 9), the results show $91 \%$ of the respondents perceived that air pollution is the most important environmental consequence from road transport. These results imply that air pollution is the most significant environmental issue in Bangkok and is mainly caused by road transport. Some respondents thought that vibration $(7 \%)$ and noise pollution $(2 \%)$ were the most important environmental problems in Bangkok caused by road transport.

Table 9. Respondents' perceptions of the use of road transport and air-quality problems.

\begin{tabular}{|c|c|c|}
\hline & Number of Responses (Person) & Percent \\
\hline \multicolumn{3}{|l|}{$\begin{array}{l}\text { The most important environmental } \\
\text { problem in Bangkok that results from } \\
\text { road transport }\end{array}$} \\
\hline Air pollution & 547 & 90.86 \\
\hline Vibrations & 43 & 7.14 \\
\hline Noise pollution & 12 & 1.99 \\
\hline Total & 602 & 100.00 \\
\hline \multicolumn{3}{|l|}{$\begin{array}{l}\text { The most important adverse result } \\
\text { from road transport }\end{array}$} \\
\hline Smog and poor visibility & 66 & 10.96 \\
\hline Dirty air and air contamination & 413 & 68.60 \\
\hline Odor pollution & 123 & 20.43 \\
\hline Total & 602 & 100.00 \\
\hline \multicolumn{3}{|l|}{$\begin{array}{l}\text { Motor vehicles are one of the causes } \\
\text { of air pollution }\end{array}$} \\
\hline Yes & 596 & 99.00 \\
\hline No & 6 & 1.00 \\
\hline Total & 602 & 100.00 \\
\hline \multicolumn{3}{|l|}{$\begin{array}{l}\text { The use of mass public transportation } \\
\text { can reduce private vehicle use, } \\
\text { reducing mobile source air pollution }\end{array}$} \\
\hline Yes & 591 & 98.17 \\
\hline No & 11 & 1.83 \\
\hline Total & 602 & 100.00 \\
\hline
\end{tabular}

Respondents were asked about the most important adverse effects of road transport pollution in Bangkok. The results show 69\% indicated that dirty air and air contamination are the most important adverse effects of road transport pollution in Bangkok, followed by odor pollution (20\%) and smog and poor visibility (11\%). 
To support respondents' understandings of the relationship between motor vehicles and air pollution, $99 \%$ of the respondents knew that motor vehicles are one cause of air pollution. However, most respondents continue to use motor vehicles because the electric rail system such as skytrain and Metropolitan Rapid Transit (MRT) cannot access all areas in Bangkok. The respondents also agreed that the use of mass public transport can reduce private vehicle use and mobile source air pollution (98\%). However, most respondents seldom use Bangkok's mass transit system. They perceive that the Bangkok mass transit system is unsafe, provides poor service, has inconvenient station locations, unkind staff, unsuitable bus schedules, and expensive prices. These findings are consistent with previous studies, which reveal the reasons why Thais do not use public transport are unsafe vehicles, unsafe drivers, bus crime, uncomfortable seats, no access to some stations, delays in the schedule, and refusing passengers the option to board [53-55].

To investigate respondents' attitudes toward air-quality policies, we asked their opinion (agreement or disagreement) on air-quality policies (scale 5 "strongly agree" to 1 "strongly disagree"). Respondents' attitudes toward air-quality policies show that they strongly agree with some policies related to public transport. For example, they agreed with the policy "the government should invest in green buses" with a mean score of 4.06. The finding supports the results of [56] who find that air-quality improvement was associated with the use of hydrogen buses in Berlin, London, Luxembourg, and Perth. Moreover, "the government should decrease rail transport fees to encourage the use of rail transport in Bangkok" (mean 3.99) This result confirms that the Bangkok mass transit system charges expensive prices, which leads to the low use of public transport (see Table 10).

Table 10. Respondents' attitudes toward air-quality policies.

\begin{tabular}{|c|c|c|}
\hline \multirow{2}{*}{ Statement } & \multicolumn{2}{|c|}{ Number of Responses (602 People) } \\
\hline & Mean * & SD \\
\hline Government attempts to reduce pollutants & 2.79 & 0.80 \\
\hline Government has a clear plan to solve air-quality problems & 2.73 & 0.83 \\
\hline Government informs people about the strategies to reduce air pollution & 2.78 & 0.84 \\
\hline Policy to reduce pollutants is intended to improve wellbeing & 2.88 & 0.93 \\
\hline Government policy to reduce air pollution can solve the causes of air-quality problems & 2.42 & 1.06 \\
\hline Government policy regarding air-quality improvement is successful & 2.29 & 1.11 \\
\hline Government spends more money to deal with air-quality problems & 2.72 & 1.07 \\
\hline The policies to reduce air pollution are designed by people's participation & 2.59 & 1.01 \\
\hline $\begin{array}{c}\text { Government asks other developed countries for help to solve the country's } \\
\text { air-quality problems }\end{array}$ & 2.58 & 1.04 \\
\hline Government requires private sectors and companies to cooperate to reduce pollutants & 2.68 & 0.99 \\
\hline Government asks scholars and scientists to find the best way to reduce air pollution & 2.72 & 1.05 \\
\hline $\begin{array}{l}\text { Government has some policies for protecting people health such as providing free } \\
\text { N95 masks }\end{array}$ & 2.70 & 1.06 \\
\hline I am satisfied with the Government actions about air-quality problems & 2.29 & 1.05 \\
\hline Government has a plan to prevent air-quality problems for the future & 2.34 & 1.06 \\
\hline Carpooling policy can lead to a reduction in the number of private vehicles in Bangkok & 3.00 & 0.95 \\
\hline $\begin{array}{l}\text { Government should subsidize people using environmentally friendly vehicles such as } \\
\text { electric cars and hybrid cars }\end{array}$ & 3.82 & 0.95 \\
\hline $\begin{array}{l}\text { Government should decrease rail transport fees to encourage the use of rail transport } \\
\text { in Bangkok }\end{array}$ & 3.99 & 0.88 \\
\hline $\begin{array}{l}\text { Government should pay subsidies to oil companies to produce gasoline and diesel that } \\
\text { has lower pollutants per litre }\end{array}$ & 3.88 & 0.94 \\
\hline Government should invest in green buses & 4.06 & 0.90 \\
\hline I do not believe that the Government policies can lead to any improvement in air quality & 3.58 & 1.05 \\
\hline
\end{tabular}

Note: * The mean is computed from values of 5 for "Strongly agree" to 1 for "Strongly disagree"; the mean scores exclude "don't know" or "not answered" responses. 
Respondents were presented with a hypothetical scenario of air pollution in Bangkok with a plan that the government proposed to solve air-quality issues. Based on the survey, 239 of 602 respondents $(39.70 \%)$ claimed they were willing to pay for air-quality improvement. This is because they think "air quality is important to the general quality of life" and "it is everybody's responsibility to improve air quality because everyone benefits from air quality improvement". However, 363 respondents $(60.30 \%)$ claimed they were unwilling to pay for air quality improvement because they already paid taxes. Thus, the Thai government should allocate part of the tax money to solve the air-quality problem. Moreover, they do not believe that the Thai government's actions can mitigate harmful substances in the air (see Table 11). Therefore, only 239 respondents who were willing to pay for improving air quality were asked to answer the two proposed bids scenario. Table 12 presents the distribution of WTP answers for the double-bounded discrete choice. The number of respondents who were willing to pay the bid significantly decreased with the increase in bid price.

Table 11. Respondents' reasons for WTP for reducing amount of particulate matter $\left(\mathrm{PM}_{2.5}\right)$ by $50 \%$.

\begin{tabular}{|c|c|c|}
\hline The Reasons for the WTP to Improve Air Quality & Number of Respondents (People) & Percentage * \\
\hline Willing to Pay & 239 & 39.70 \\
\hline $\begin{array}{c}\text { It is people's responsibility to improve air quality because everyone } \\
\text { benefits from air-quality improvement }\end{array}$ & 170 & 71.13 \\
\hline Air quality improvement generates greater benefits for people's health & 174 & 72.80 \\
\hline Air quality is important to the general quality of life & 171 & 71.55 \\
\hline $\begin{array}{c}\text { Air quality improvement reduced the expenditure on } \\
\text { respiratory diseases }\end{array}$ & 135 & 56.49 \\
\hline I would like to participate in air-quality improvement & 147 & 61.51 \\
\hline There are family members who have respiratory illnesses & 93 & 38.91 \\
\hline $\begin{array}{c}\text { There are family members who are sensitive to air pollution such as } \\
\text { children and elderly }\end{array}$ & 102 & 42.68 \\
\hline I also produce air pollution, so I do feel responsible for this problem & 113 & 47.28 \\
\hline It is a social trend to be concerned about air pollution in Bangkok & 88 & 36.82 \\
\hline I am very knowledgeable about the serious effects of air pollution & 82 & 34.31 \\
\hline Unwilling to Pay & 363 & 60.30 \\
\hline Air quality problems are not important & 25 & 6.89 \\
\hline There are regulations governing the safety of air quality & 76 & 20.94 \\
\hline It is the Government's responsibility to protect air quality & 91 & 25.07 \\
\hline I already pay taxes & 198 & 54.55 \\
\hline I do not get any benefits from air-quality improvement & 62 & 17.08 \\
\hline $\begin{array}{c}\text { I do not believe that the Thai government's actions can mitigate } \\
\text { harmful substances in the air }\end{array}$ & 130 & 35.81 \\
\hline I do not produce air pollution, so I do not have to be responsible & 33 & 9.09 \\
\hline $\begin{array}{l}\text { The developed countries should donate money to reduce air pollution } \\
\text { in Bangkok }\end{array}$ & 39 & 10.74 \\
\hline I cannot afford it because my income is too low & 54 & 14.88 \\
\hline $\begin{array}{c}\text { Air quality is still good; thus, we do not need to pay extra money to } \\
\text { improve it }\end{array}$ & 5 & 1.38 \\
\hline
\end{tabular}

Note: * The percentages total over 100 because respondents can check all that apply. 
Table 12. Distribution of WTP responses for the double-bounded discrete choice. Unit: Person (Percent).

\begin{tabular}{|c|c|c|c|c|c|c|c|c|}
\hline \multirow{3}{*}{$\begin{array}{c}\text { Bid } \\
\text { Version }\end{array}$} & \multicolumn{3}{|c|}{ Bid Amount (Baht) } & \multicolumn{4}{|c|}{ Distribution of WTP Responses } & \multirow{3}{*}{$\begin{array}{c}\text { No. of } \\
\text { Responses }\end{array}$} \\
\hline & \multirow{2}{*}{ First Bid } & \multicolumn{2}{|c|}{ Second Bid } & \multirow{2}{*}{ Yes/Yes } & \multirow{2}{*}{ Yes/No } & \multirow{2}{*}{ No/Yes } & \multirow{2}{*}{ No/No } & \\
\hline & & Lower Amount & Upper Amount & & & & & \\
\hline $\mathrm{A}$ & 500 & 250 & 1000 & $\begin{array}{c}62 \\
(10.30)\end{array}$ & $\begin{array}{c}45 \\
(7.48)\end{array}$ & $\begin{array}{c}2 \\
(0.33)\end{array}$ & $\begin{array}{c}42 \\
(6.98)\end{array}$ & $\begin{array}{c}151 \\
(25.08)\end{array}$ \\
\hline $\mathrm{B}$ & 1000 & 500 & 2000 & $\begin{array}{c}20 \\
(3.32)\end{array}$ & $\begin{array}{c}36 \\
(5.98)\end{array}$ & $\begin{array}{c}16 \\
(2.66)\end{array}$ & $\begin{array}{c}78 \\
(12.96)\end{array}$ & $\begin{array}{c}150 \\
(24.92)\end{array}$ \\
\hline $\mathrm{C}$ & 2000 & 1000 & 4000 & $\begin{array}{c}5 \\
(0.83)\end{array}$ & $\begin{array}{c}22 \\
(3.65)\end{array}$ & $\begin{array}{c}7 \\
(1.16)\end{array}$ & $\begin{array}{c}116 \\
(19.27)\end{array}$ & $\begin{array}{c}150 \\
(24.92)\end{array}$ \\
\hline $\mathrm{D}$ & 4000 & 2000 & 8000 & $\begin{array}{c}4 \\
(0.66)\end{array}$ & $\begin{array}{c}4 \\
(0.66)\end{array}$ & $\begin{array}{c}16 \\
(2.66)\end{array}$ & $\begin{array}{c}127 \\
(21.10)\end{array}$ & $\begin{array}{c}151 \\
(25.08)\end{array}$ \\
\hline & & Total & & $\begin{array}{c}91 \\
(15.12)\end{array}$ & $\begin{array}{c}107 \\
(17.77)\end{array}$ & $\begin{array}{c}41 \\
(6.81)\end{array}$ & $\begin{array}{c}363 \\
(60.30)\end{array}$ & $\begin{array}{c}602 \\
(100.00)\end{array}$ \\
\hline
\end{tabular}

As discussed in the methodology section, data from the double-bounded WTP were fitted to three probability distribution functions: log-normal, log-logistic and Weibull distribution [14]. The maximum log-likelihood values of these distributions functions (without explanatory variables) was used for comparison to choose the distribution functions that fit the double-bounded WTP data [14,42]. Table 13 shows Model 2 provides the lowest maximum log-likelihood value compared with Model 1 for all three probability distribution functions used. Thus, Model 2 is not suitable for estimating WTP for air-quality improvement because the model provided the lowest loglikelihood value, which indicates a poor goodness-of-fit measure compared with Model 1.

Table 13. Log-likelihood value functions.

\begin{tabular}{|c|c|c|c|c|}
\hline \multirow[b]{3}{*}{ Distributions } & \multicolumn{4}{|c|}{ Maximum Log-Likelihood Value } \\
\hline & \multicolumn{2}{|c|}{ Model 1} & \multicolumn{2}{|c|}{ Model 2} \\
\hline & $\begin{array}{c}\text { Restricted Equation } \\
\text { (Without Explanatory } \\
\text { Variables) } \\
\left(\mathrm{Lnl}_{0}\right)\end{array}$ & $\begin{array}{c}\text { Unrestricted Equation } \\
\text { (With Explanatory } \\
\text { Variables) } \\
\left(\operatorname{Lnl}_{1}\right)\end{array}$ & $\begin{array}{c}\text { Restricted Equation } \\
\text { (Without Explanatory } \\
\text { Variables) } \\
\left.\text { (Lnl })_{0}\right)\end{array}$ & $\begin{array}{c}\text { Unrestricted Equation } \\
\text { (With Explanatory } \\
\text { Variables) } \\
\left(\text { Lnl }_{1}\right)\end{array}$ \\
\hline Log-normal & $-270,332$ & $-182,842$ & $-266,924$ & $-288,068$ \\
\hline Log-logistic & $-273,312$ & $-184,277$ & $-270,828$ & $-299,474$ \\
\hline Weibull & $-290,617$ & $-189,421$ & $-293,259$ & $-243,973$ \\
\hline
\end{tabular}

Model 1 estimates the mean and median WTP values for air-quality improvement. The estimated mean WTP value to improve air quality was 2275.163 baht/person/year. Likewise, the estimated median WTP value to improve air quality was $1760.142 \mathrm{baht} /$ person/year. Based on the 95\% confidence intervals (CI) of mean and median WTP values for air-quality improvement, the estimated $95 \%$ CI of mean WTP value for improving air quality was between 1965.45 and 2584.88 baht/person/year. Similarly, the estimated $95 \%$ CI of median WTP value to improve air quality was between 1572.480 and 1947.804 baht/person/year.

The empirical results for the estimated mean and median WTP values imply that if air quality is improved, people will gain a benefit of $2275 \mathrm{baht} /$ person/year (mean WTP) or $1760.142 \mathrm{baht} /$ person/year (median WTP value). The number of residents in Bangkok was 8,280,925 persons in 2020 [57]. Therefore, the total benefit that people will gain from air-quality improvement is $18,839,104,375$ baht in 2020 (mean WTP value) or 14,574,428,000 baht in 2020 (median WTP value).

By this finding, people will benefit significantly from air-quality improvement compared with the expenditure budget that the Thai Government allocates to deal with air pollution. The budgets for air pollution and air-quality management between 2007 and 
2018 ranged from $0.28 \%$ to $0.48 \%$ of the total government budget with an average of $0.36 \%$ (see Table 14). This is a very small amount, which results in the inability to solve air pollution problems [6].

Table 14. A comparison of budgets for air pollution and air-quality management with the total budget of Ministry of Natural Resources and Environment from 2007 to 2018.

\begin{tabular}{cccc}
\hline Year & $\begin{array}{c}\text { Total Budget of Ministry } \\
\text { of Natural Resources } \\
\text { and Environment } \\
\text { (Million Baht) }\end{array}$ & $\begin{array}{c}\text { The Budget for Air } \\
\text { Pollution and Air } \\
\text { Quality Management } \\
\text { (Million Baht) }\end{array}$ & $\begin{array}{c}\text { Percentage of the } \\
\text { Budget for Air } \\
\text { Pollution from the } \\
\text { Total Budget }\end{array}$ \\
\hline 2007 & $1,566,200$ & 4636 & 0.29 \\
2008 & $1,660,000$ & 5784 & 0.35 \\
2009 & $1,835,000$ & 5314 & 0.30 \\
2010 & $1,700,000$ & 8117 & 0.48 \\
2011 & $2,070,000$ & 8928 & 0.43 \\
2012 & $2,380,000$ & 6691 & 0.28 \\
2013 & $2,400,000$ & 9614 & 0.40 \\
2014 & $2,525,000$ & 8755 & 0.35 \\
2015 & $2,575,000$ & 9205 & 0.36 \\
2016 & $3,364,000$ & 12,110 & 0.36 \\
2017 & $3,418,000$ & 12,305 & 0.36 \\
2018 & $3,588,000$ & 12,917 & 0.36 \\
\hline
\end{tabular}

Source: Ministry of Natural Resources and Environment (2018).

Air pollution and air-quality problems in Thailand remain unresolved and are worsening. Furthermore, Thai people bear the costs of protecting themselves from air pollution. On average, individuals spent over 18 USD (600 baht) a month on masks and protective products to counter the effects of air pollution [58]. This is a private cost that Thai people pay to protect themselves from air pollution and amounted to 59.6 billion baht in 2018 (600 baht $\times 12$ months $\times 8,280,925$ persons). This private cost is an additional cost to other impairment costs such as medical expenses. The ongoing air pollution problem can cause severe economic damage [6,33]. Severe air pollution led to the loss of $1-2 \%$ of foreign tourists per month. This loss would affect tourism revenue by approximately 31-109 million USD [59]. The numbers clearly show that the total benefit that people will gain from air-quality improvement is much more than Thailand's environmental expenditure budget for air pollution. Therefore, the Thai government should demonstrate its commitment to solving the air-quality problems by increasing environmental expenditure on air pollution reduction; otherwise, the inappropriate, insufficient budget will exacerbate the damage costs because of air pollution forcing people to bear the brunt of the Thai Government's mismanagement.

Our study's findings also elucidate factors influencing people's WTP for air-quality improvement. The results showed that the Occ1, Occ3, Occ4, Occ5, Occ6, Inc1, Inc6, Inc8, Area, Act, Knowledge, Think and GAtti coefficients were significant at various levels $(10 \%, 5 \%$ and $1 \%$ levels) (see Table 15$)$. The coefficients of the occupation variable including government officer (Occ1), private company office (Occ3), self-employed (Occ4), farmer (Occ5), and labourer (Occ6) were positive and significant at the $5 \%$ and $10 \%$ levels, respectively. These results imply that respondents employed in better paying jobs are willing to pay more to improve air quality than those who are unemployed. This finding agrees with [60] that respondents having occupations of businessmen, government workers, and local workers tend to exhibit higher WTP to improve air quality in China. This result could be explained by the fact that these respondents have higher income, are better educated, and find it easier to obtain information about air pollution. Thus, it is more likely that they would like to pay more for air-quality improvement. 
Table 15. Estimated results of determinants of people's WTP for air-quality improvement.

\begin{tabular}{|c|c|c|c|}
\hline Variables & Coefficient & Standard Error & $p$-Value \\
\hline Gender & -29.21 & 166.64 & 0.86 \\
\hline Age1 & -2.74 & 777.68 & 1.00 \\
\hline Age2 & -739.04 & 582.11 & 0.20 \\
\hline Age3 & -151.09 & 577.89 & 0.79 \\
\hline Age4 & -831.09 & 616.98 & 0.18 \\
\hline Sta & -97.76 & 208.65 & 0.64 \\
\hline Edu & 41.25 & 39.31 & 0.29 \\
\hline Occ1 & $1082.92 * *$ & 505.53 & 0.03 \\
\hline Occ2 & 381.71 & 630.86 & 0.55 \\
\hline Occ3 & $1177.51 * *$ & 492.71 & 0.02 \\
\hline Occ4 & $1355.74^{* *}$ & 524.11 & 0.01 \\
\hline Occ5 & $2082.67^{* *}$ & 875.93 & 0.02 \\
\hline Occ6 & $1131.98 *$ & 598.98 & 0.06 \\
\hline Mem1 & -233.31 & 209.98 & 0.27 \\
\hline Mem2 & -14.61 & 139.85 & 0.92 \\
\hline Mem3 & 123.64 & 122.77 & 0.31 \\
\hline Mem4 & 46.30 & 159.92 & 0.77 \\
\hline IncEarn & -221.64 & 166.81 & 0.18 \\
\hline Inc1 & $-1180.24^{* * *}$ & 469.66 & 0.01 \\
\hline Inc2 & -532.45 & 451.63 & 0.24 \\
\hline Inc3 & -409.35 & 467.94 & 0.38 \\
\hline Inc4 & -95.34 & 434.66 & 0.83 \\
\hline Inc5 & -306.50 & 415.60 & 0.46 \\
\hline Inc6 & $-773.76^{*}$ & 475.24 & 0.10 \\
\hline Inc7 & -642.10 & 441.15 & 0.15 \\
\hline Inc8 & $-1090.10^{* *}$ & 485.63 & 0.03 \\
\hline SickLastTwo & 234.64 & 234.27 & 0.32 \\
\hline APZone & -403.94 & 259.77 & 0.12 \\
\hline CZone & -187.94 & 204.36 & 0.36 \\
\hline Area & $-301.53 *$ & 181.33 & 0.10 \\
\hline Act & $621.96^{* * *}$ & 187.30 & 0.00 \\
\hline Donate & 131.17 & 193.09 & 0.50 \\
\hline Knowledge & $520.36^{* * *}$ & 128.11 & 0.00 \\
\hline Aware & 54.93 & 142.36 & 0.70 \\
\hline Atti & -84.37 & 262.79 & 0.75 \\
\hline Think & $496.58^{* *}$ & 214.95 & 0.02 \\
\hline GAtti & $-397.76^{* *}$ & 182.49 & 0.03 \\
\hline _cons & -1879.35 & 1433.98 & 0.19 \\
\hline $\ln \mathrm{L}_{0} \mathrm{~A}$ & & -270.33 & \\
\hline $\ln \mathrm{L}_{1} \mathrm{~B}$ & & -182.84 & \\
\hline Pseudo $\mathrm{R}^{2}=1-\frac{\ln \mathrm{L}_{0}}{\ln \mathrm{L}_{1}}$ & & 32.36 & \\
\hline No. of observations & & 239.00 & \\
\hline
\end{tabular}

Respondents with low income (Inc1) exhibit a negative and significant influence on WTP to improve air quality. People with a low income face financial challenges in making a living for their families, thus they are generally less willing and able to pay to improve air quality. Interestingly, respondents with a high income (Inc6) and (Inc8) also exhibited a negative, significant impact on the WTP for air-quality improvement. This may be because the respondents with high incomes feel they have paid a lot of taxes compared with lowincome people. Therefore, they are not willing to pay more to improve air quality. This was confirmed by the results. Respondents with high incomes and their families do not usually suffer from ambient air pollution because they use private cars to travel. Likewise, most of these respondents live in healthy environments and can easily buy devices to purify the 
air to protect themselves from air pollution. For example, respondents with high income always use an air purifier in their house. This was confirmed by the survey.

The results show a negative relationship between the Area coefficient and the WTP to improve air quality. Respondents who live in the city are desensitised to the contaminated air because of long-term exposure to air pollution. Thus, respondents who live in the city are more adapted to living in a contaminated environment than respondents who live in the suburbs. This can be explained by the fact that urban living places are designed to prevent air pollution such as installing ventilators in the house, and using air conditioning systems, unlike suburban open space living places. Moreover, [61,62] explain that respondents who live in urban areas face a high cost of living. Thus, consideration of clean air is not their priority. As a result, respondents living in cities were less likely to pay to improve air quality.

Regarding personal lifestyle (Act), this estimated coefficient was positive and significantly affected WTP for air-quality improvement. However, this finding is not seen in any previous study. Almost all outdoor activities in Thailand are outside the air-polluted areas (in the provinces). Respondents who prefer outdoor activities need to go out of the city to participate in these activities. Thus, they may not feel that air pollution is an issue, so they are less willing to pay to improve air quality.

Knowledge regarding air pollution (Knowledge) coefficient was the key determinant of the people's WTP for air-quality improvement. Respondents with higher knowledge about air pollution exhibit an increased likelihood of WTP to improve air quality. Knowledge about severe adverse effects of air pollution often leads to an increase in awareness of the health risks [21,26,59]. Our study shows that people who have more knowledge about air pollution are more willing to pay for air-quality improvement.

People's attitude toward the use of road transport (Think) coefficient was positive and significantly associated with the WTP to improve air quality. The results imply that respondents who are concerned about air-quality problems when using road transport are more willing to pay to improve air quality. This is a significant factor in explaining WTP to improve air quality because road transport is the main cause of air quality problems in Thailand.

Attitudes toward air-quality policies (GAtti) coefficient exhibited a negative, significant effect on the WTP to improve air quality. The result implies that respondents who do not believe that Thai government policies can solve air-quality problems are willing to pay more to improve air quality. In other words, if people believe that the government performance regarding air-quality policies is poor, they are willing to pay more to improve air quality.

\section{Implications}

This study applies CVM to elicit people's WTP for air-quality improvement in Bangkok, because air-quality improvement relates to estimating a value for a specified and fixed set of holistic changes. The CVM is well suited to conceptualise and measure people's WTP to improve air quality. The air-quality problems in Thailand result from contamination by many pollutants such as sulphur dioxide $\left(\mathrm{SO}_{2}\right), \mathrm{O}_{3}$, carbon monoxide (CO), $\mathrm{NO}_{2}, \mathrm{PM}_{10}$, and $\mathrm{PM}_{2.5}$. In a situation such as this, parsing the whole into its component attributes or characteristics might not fully capture the comprehensive value that respondents hold or may mischaracterize the way in which they understand air-quality improvements. The study's findings confirm that the CVM adequately captures people's WTP to improve air quality. The findings also suggest that the use of CVM facilitates a solution to the estimation of a value for a specified and fixed set of holistic changes.

The socio-demographic characteristics reveal that $83 \%$ of respondents had suffered a respiratory illness in the previous 2 years and most respondents were concerned about the health consequences of poor air quality. Therefore, the Ministry of Public Health should provide free respiratory illness checks. In addition, our findings confirm that people do not have a deep level of knowledge about air pollution, especially how to 
protect themselves from air pollution. Knowledge about air pollution is significant in explaining factors influencing people's WTP for air-quality improvement in our study. People who have more knowledge about air pollution are willing to pay more for air-quality improvement. Thus, the Ministry of Public Health, related departments, or the universities should provide seminars to educate people about how to protect themselves from air pollution. Furthermore, the Ministry of Education should consider providing a healthrelated course taught in schools and universities including the prevention of air pollution, the causes of air pollution, and the steps people can take to reduce air pollution. However, our findings show that most respondents would not be able to attend these courses. This is because these courses on the effects of air pollution are scheduled on weekdays. Therefore, the Thai government, related departments, and universities need to reconsider the day and time when organising courses and organisers/presenters should record these seminars and post them on the government website (e.g., http:/ / air4thai.pcd.go.th/webV2/ (accessed on 10 April 2021)).

The study's findings may also be useful for the Bangkok Mass Transit Authority and Department of Land Transport to enhance the quality of mass public transport including providing good service, convenient stations, friendly staff, suitable bus schedules, and fair prices. This can increase the use of mass public transport and lead to improved air quality. This is likely because our results confirm that people agree that "improving the public transport system could lead to reducing the number of private vehicles in Bangkok", "using public transport to reduce air pollution is a good idea" and "improved public transport networks can reduce air pollution in Bangkok". The study's findings can be used to improve the electric rail system. The results clearly show that increasing the range of routes and decreasing the fees for rail transport would encourage people to use rail transport in Bangkok. Thus, the Ministry of Transport should invest more in creating more routes for the Skytrain and MRT to access all areas in Bangkok with fair prices.

The empirical results show respondents agree that air pollution is the major environmental problem. They also agree that the main source of air pollution is road transport. However, the air-quality problem is not a sufficient imperative to make them stop using road transport. This is because the electric rail transport systems lack the ability to access all areas in Bangkok. Moreover, the study's results show the respondents prefer to use private motor vehicles because of the inconvenience of using public transport coupled with risks to personal safety. Therefore, to solve the air-quality problem, policymakers should develop and implement an effective policy related to the use of road transport, especially private motor vehicles.

- Previous studies recommend that policymakers should limit the use of private motor vehicle by increasing the costs of using them [38,39]. Limiting private vehicle use leads to a decrease in mobile sources of air pollution. Thus, the Expressway Authority of Thailand should increase toll-road fees, the Ministry of Energy should consider increasing the rate of gasoline tax, and the Bangkok Metropolitan Administration (BMA) and related authorities should consider setting congestion fees in certain areas of Bangkok.

- Some prior studies recommended that policymakers should strictly enforce regulations about controlling the quality of motor vehicles to reduce impacts on the environment $[20,62,63]$. For instance, car owners need to obtain an emissions test/car inspection annually, and installation of pollution reductions systems such as catalytic converters on all gasoline and diesel cars.

- Policymakers should implement some incentive policies [64,65]. For example, the Ministry of Energy should subsidise oil companies and refineries to produce gasoline and diesel that have lower pollutants per litre. The Ministry of Transport and the Ministry of Natural Resources and Environment should subsidize people using environmentally friendly vehicles such as electric and hybrid cars, and the Ministry of Transport and related authorities should decrease rail transport fees to encourage the use of rail transport in Bangkok. 
- The BMA and related authorities should design strategies to reduce the use of motor vehicles in some areas in Bangkok including the creation of non-traffic zones, encourage motorists to give up driving for a day (car-free day), increase opportunities for people to ride a bicycle (such as bicycle lanes), and increase opportunities for people to walk (such as skywalks).

The study's findings can be used as guidelines for the government's expenditure budget to deal with air pollution. The empirical results show the total benefit that people will gain if air quality is improved is 18.8 billion baht (mean WTP) or 14.5 billion baht (median WTP) in 2020. Thailand's environmental expenditure budget for air pollution was 10.9 billion baht in 2020 . The numbers clearly show that the budget set aside for air-quality protection is extremely small compared with the benefits that everyone will gain from air-quality improvement. The difference between the budget (cost) and the benefit (median WTP) is around $30 \%$. Likewise, the difference between the budget (cost) and the benefit (mean WTP) is about $70 \%$. Therefore, the Thai government should consider increasing the expenditure budget to deal with air pollution by between $30 \%$ and $70 \%$. In other words, Thailand's environmental expenditure budget for improving air quality should increase to 14.5 or 18.8 billion baht.

Likewise, the findings make a significant contribution to the literature on the estimation of WTP for air-quality improvement. This is the first study to estimate the benefits of air-quality improvement in Thailand. Previous studies in Thailand estimated the damage or cost of air pollution [5,25]. Those results provide the total damage or cost that people incur when air is contaminated by pollutants. The estimated monetary value from air-quality improvement indicates the importance of improving air quality for people in Thailand. Critically, this value can be used to provide key information to the Thai Government to effectively solve air-quality problems.

\section{Limitations of the Study}

A major limitation relates to methodological concerns when using the CVM methodology. The validity of the true value of environmental goods and services that the CVM uses from the experiment combines content, criterion, and construct validity $[66,67]$. The reliability of the CVM is associated with the consistency or repeatability measurement of estimates in the CVM survey. The reliability of the CVM is expressed through attribution of the variance of the WTP responses to the random disturbance, in terms of a reverse relationship between reliability and the degree of non-randomness [68]. In other words, a reliable method results in similar measurements if nothing has changed in the true value of the commodity in replicated experiments. If the commodity's true value changes, the method would change its measurements accordingly. This study applied mobile phone, face time/VDO calls, and an email survey instead of a self-administered questionnaire or face-to-face interviews because of the COVID-19 pandemic. The study's findings probably share this effect because the time that respondents took to think about their WTP had an effect on their WTP values [19].

Author Contributions: Conceptualization, C.G. and W.Y.; Data curation, W.T.; Investigation, W.T.; Methodology, W.T. and C.G.; Project administration, W.T.; Resources, W.T.; Supervision, C.G. and W.Y.; Visualization, C.G. and W.Y.; Writing-original draft, W.T.; Writing—review and editing, C.G. and W.Y. All authors have read and agreed to the published version of the manuscript.

Funding: This research received no external funding.

Institutional Review Board Statement: The study was conducted according to the guidelines of the Lincoln University Human Ethics Committee, Lincoln University, Christchurch, New Zealand. This study was reviewed and approved by the Lincoln University Human Ethics Committee on 5 June 2020. 
Informed Consent Statement: This research is completely voluntary in nature, and you are free to decide not to participate at any time during the process of completing the questionnaire and without prejudice, including withdrawal of any information you have provided. However, if you answer all the questions in the questionnaire that I will ask, it will be understood that you are 18 years of age or older and have consented to participate in this survey and consent to publication of the results of this research with the understanding the anonymity will be preserved. Only summary results and conclusions from this survey will be reported without giving any of your personal details.

Data Availability Statement: Not applicable.

Conflicts of Interest: The authors declare no conflict of interest.

$\begin{array}{ll}\text { Abbreviations } & \\ \text { World Health Organization } & \\ \text { Particulate Matter that have a diameter of less than } 2.5 \mu \mathrm{m} & \mathrm{PM}_{2.5} \\ \text { Nitrogen Dioxide } & \mathrm{NO}_{2} \\ \text { Ground-level Ozone } & \mathrm{O}_{3} \\ \text { Particulate Matter that have a diameter of less than 10 } \mathrm{mm} & \mathrm{PM}_{10} \\ \text { Willingness to Pay } & \mathrm{WTP} \\ \text { Contingent Valuation Method } & \mathrm{CVM} \\ \text { United States Dollars } & \mathrm{USD} \\ \text { Swedish Krona } & \mathrm{SEK} \\ \text { Euro } & \mathrm{EUR} \\ \text { Gross Domestic Product } & \mathrm{GDP} \\ \text { Polish Zloty } & \mathrm{PLN} \\ \text { Canadian Dollar } & \mathrm{CAD} \\ \text { Iranian Rial } & \mathrm{IRR} \\ \text { Chinese Yuan } & \mathrm{CNY} \\ \text { Subjective Well-being Approach } & \mathrm{SWB} \\ \text { National Oceanic and Atmospheric Administration } & \mathrm{NOAA} \\ \text { Metropolitan Rapid Transit } & \mathrm{MRT} \\ \text { sulphur dioxide } & \mathrm{SO} 2 \\ \text { carbon monoxide } & \mathrm{CO} \\ \text { Bangkok Metropolitan Administration } & \mathrm{BMA}\end{array}$

\section{References}

1. Wang, Y.; Sun, M.; Yang, X.; Yuan, X. Public awareness and willingness to pay for tackling smog pollution in China: A case study. J. Clean. Prod. 2016, 112, 1627-1634. [CrossRef]

2. Du, X.; Mendelsohn, R.O. Estimating the value of the reduction in air pollution during the Beijing Olympics. Environ. Dev. Econ. 2011, 16, 735-749. [CrossRef]

3. Wang, K.; Wu, J.; Wang, R.; Yang, Y.; Chen, R.; Maddock, J.E.; Lu, Y. Analysis of residents' willingness to pay to reduce air pollution to improve children's health in community and hospital settings in Shanghai, China. Sci. Total Environ. 2015, 533, 283-289. [CrossRef] [PubMed]

4. The Cost of Air Pollution Strengthening the Economic Case for Action. Available online: http://documents.worldbank.org/99F3 A48D-6A40-45BC-9345-23D0402383BD/FinalDownload/DownloadId-8C839D0F7C6ACE4E519FDBE9E227B57A/99F3A48D6A40-45BC-9345-23D0402383BD/curated/en/781521473177013155/pdf/108141-REVISEDCost-of-PollutionWebCORRECTEDfile. pdf (accessed on 15 July 2018).

5. Attavanich, W. Impact of the First-Time Car Buyer Program on The Environmental Cost Of Air Pollution in Bangkok. Available online: http:/ / pubdocs.worldbank.org/en/506781491896176918/Impact-of-the-First-Time-Car-Buyer-Program-Paper.pdf (accessed on 11 July 2018).

6. Booklet on Thailand State of Pollution 2018. Available online: http://www.pcd.go.th/file/Booklet $\% 20$ on $\% 20$ Thailand\%20State\% 20of\%20Pollution\%202018.pdf (accessed on 10 July 2020).

7. Top 10 cities in the World with the Worst Air Pollution. Available online: https://www.epa.gov/airtrends/air-quality-cities-andcounties (accessed on 15 July 2018).

8. Ministry of Natural Resources and Environment. Annual Air Quality. Available online: http://aqnis.pcd.go.th (accessed on 10 July 2018). (In Thai).

9. Number of Vehicles Registered in Bangkok. Available online: http://apps.dlt.go.th/statistics_web/vehicle.html (accessed on 15 July 2018). 
10. Greenpeace's City Rankings for PM2.5 in Thailand. Available online: https://greenpeace.or.th/s/right-to-clean-air/PM2.5 CityRankingsREV.pdf (accessed on 1 July 2018).

11. Premature Mortality Situation of Non-Communicable Diseases. Available online: https://www.msociety.go.th/article_attach/18 953/20526.pdf (accessed on 10 July 2020).

12. Wangwongwattana, S. Assessment of Health Benefit from Air Quality Improvement in Thailand: From Concept to Applications. Available online: https://www.baq-2018.org/wp-content/uploads/2018/11/November-15_Thailand-BenMAP-Application_ Thao.pdf. (accessed on 29 July 2021).

13. Wang, Y.; Zhang, Y.S. Air quality assessment by contingent valuation in Ji'nan, China. J. Environ. Manag. 2009, 90, 1022-1029. [CrossRef] [PubMed]

14. Bateman, I.J.; Carson, R.T.; Day, B.; Hanemann, M.; Hanleys, N.; Hett, T.; Jones-Lee, M.; Loomes, G.; Mourato, S.; Ozdemiroglu, E.; et al. Economic Valuation with Stated Preference Techniques: A Manual; Edward Elgar Cheltenham: Cheltenham, UK, 2002; Volume 1, pp. 11-29. ISBN 1840649194.

15. Johnston, R.J.; Boyle, K.J.; Adamowicz, W.; Bennett, J.; Brouwer, R.; Cameron, T.A.; Hanemann, W.M.; Hanley, N.; Ryan, M.; Scarpa, R.; et al. Contemporary guidance for stated preference studies. J. Assoc. Environ. Resour. Econ. 2017, 4, 319-405. [CrossRef]

16. Barwick, P.J.; Li, S.; Rao, D.; Zahur, N.B. Air pollution, health spending and willingness to pay for clean air in China. SSRN Electron. J. 2017, 1, 15. [CrossRef]

17. Mendoza, Y.; Loyola, R.; Aguilar, A.; Escalante, R. Valuation of air quality in Chile: The life satisfaction approach. Soc. Indic. Res. 2019, 145, 367-387. [CrossRef]

18. Wang, B.; Hong, G.; Qin, T.; Fan, W.R.; Yuan, X.C. Factors governing the willingness to pay for air pollution treatment: A case study in the Beijing-Tianjin-Hebei region. J. Clean. Prod. 2019, 235, 1304-1314. [CrossRef]

19. Donfouet, H.; Cook, J.; Jeanty, P.W. The economic value of improved air quality in urban Africa: Results from Douala, Cameroon. Environ. Dev. Econ. 2013, 20, 630-649. [CrossRef]

20. Maloma, I.; Sekatane, M.B. Factors that determine the stated willingness to pay for air pollution: A case of Bophelong Township. Int. J. Soc. Sci. Hum. Stud. 2014, 6, 1-11.

21. Ndambiri, H.; Mungatana, E.; Brouwer, R. Stated preferences for improved air quality management in the city of Nairobi, Kenya/Vrednovanje Iskazanih Preferencija Za Unapređenje Kvaliteta Vazduha U Gradu Najrobi U Keniji. Eur. J. Appl. Econ. 2015, 12, 16-26. [CrossRef]

22. Wang, H.; Whittington, D. Willingness to Pay for Air Quality Improvements in Sofia, Bulgaria; World Bank Publications: Washington, DC, USA, 2000; Volume 2280.

23. Carlsson, F.; Johansson-Stenman, O. Willingness to pay for improved air quality in Sweden. Appl. Econ. 2000, 32, 661-669. [CrossRef]

24. Alberini, A.; Chiabai, A. Urban environmental health and sensitive populations: How much are the Italians willing to pay to reduce their risks? Reg. Sci. Urban Econ. 2007, 37, 239-258. [CrossRef]

25. Vlachokostas, C.; Achillas, C.; Slini, T.; Moussiopoulos, N.; Banias, G.; Dimitrakis, I. Willingness to pay for reducing the risk of premature mortality attributed to air pollution: A contingent valuation study for Greece. Atmos. Pollut. Res. 2011, 2, $275-282$. [CrossRef]

26. Dziegielewska, D.A.P.; Mendelsohn, R. Valuing air quality in Poland. Environ. Resour. Econ. 2005, 30, 131-163. [CrossRef]

27. Ligus, M. Measuring the willingness to pay for improved air quality: A contingent valuation survey. Pol. J. Environ. Stud. 2018, 27, 915. [CrossRef]

28. Lera-López, F.; Sánchez, M.; Faulin, J.; Cacciolatti, L. Rural environment stakeholders and policy making: Willingness to pay to reduce road transportation pollution impact in the Western Pyrenees. Transp. Res. Part D Transp. Environ. 2014, 32, 129-142. [CrossRef]

29. Poder, T.G.; He, J. Willingness to pay for a cleaner car: The case of car pollution in Quebec and France. Energy 2017, 130, 48-54. [CrossRef]

30. Filippini, M.; Martínez-Cruz, A.L. Impact of environmental and social attitudes, and family concerns on willingness to pay for improved air quality: A contingent valuation application in Mexico City. Lat. Am. Econ. Rev. 2016, 25, 7. [CrossRef]

31. Firooz Zare, A.; Ghorbani, M. Investigation of Citizens WTP for Mashhad Air Pollution Reduction: Applying Heckit model. Symp. Adv. Sci. Technol. 2011, 15, 2015.

32. Lee, Y.J.; Lim, Y.W.; Yang, J.Y.; Kim, C.S.; Shin, Y.C.; Shin, D.C. Evaluating the PM damage cost due to urban air pollution and vehicle emissions in Seoul, Korea. J. Environ. Manag. 2011, 92, 603-609. [CrossRef] [PubMed]

33. Akhtar, S.; Saleem, W.; Nadeem, V.M.; Shahid, I.; Ikram, A. Assessment of willingness to pay for improved air quality using contingent valuation method. Glob. J. Environ. Sci. Manag. 2017, 3, 279-286.

34. Chen, L.; Shi, M.; Li, S.; Gao, S.; Zhang, H.; Sun, Y.; Mao, J.; Bai, Z.; Wang, Z.; Zhou, J. Quantifying public health benefits of environmental strategy of PM2.5 air quality management in Beijing-Tianjin-Hebei region, China. J. Environ. Sci. 2017, 57, 33-40. [CrossRef] [PubMed]

35. Wei, W.; Wu, Y. Willingness to pay to control PM2.5 pollution in Jing-Jin-Ji Region, China. Appl. Econ. Lett. 2017, $24,753-761$. [CrossRef]

36. Liu, R.; Liu, X.; Pan, B.; Zhu, H.; Yuan, Z.; Lu, Y. Willingness to Pay for Improved Air Quality and Influencing Factors among Manufacturing Workers in Nanchang, China. Sustainability 2018, 10, 1613. [CrossRef] 
37. Masahina, S.; Afroz, R.; Duasa, J.; Mohamed, N. A framework to estimate the willingness to pay of household for air quality improvement: A case study in Klang Valley, Malaysia. OIDA Int. J. Sustain. Dev. 2012, 4, 11-16.

38. Bazrbachi, A.; Sidique, S.F.; Shamsudin, M.N.; Radam, A.; Kaffashi, S.; Adam, S.U. Willingness to pay to improve air quality: A study of private vehicle owners in Klang Valley, Malaysia. J. Clean. Prod. 2017, 148, 73-83. [CrossRef]

39. Vassanadumrongdee, S.; Matsuoka, S. Risk perceptions and value of a statistical life for air pollution and traffic accidents: Evidence from Bangkok, Thailand. J. Risk Uncertain. 2005, 30, 261-287. [CrossRef]

40. Sekaran, U.; Bougie, R. Research Methods for Business: A Skill Building Approach, 7th ed.; John Wiley \& Sons: New York, NY, USA, 2016; ISBN 0471203661.

41. Cameron, T.A.; Huppert, D.D. Referendum contingent valuation estimates: Sensitivity to the assignment of offered values. J. Am. Stat. Assoc. 1991, 86, 910-918. [CrossRef]

42. Lusk, J.L.; Hudson, D. Willingness-to-pay estimates and their relevance to agribusiness decision making. Appl. Econ. Perspect. Policy 2004, 26, 152-169. [CrossRef]

43. Hanemann, M.; Loomis, J.; Kanninen, B. Statistical efficiency of double-bounded dichotomous choice contingent valuation. Am. J. Agric. Econ. 1991, 73, 1255-1263. [CrossRef]

44. Cooper, J.C.; Hanemann, M. Referendum contingent valuation: How many bounds are enough? Am. J. Agric. Econ. 1994, 76, 1246.

45. Cuccia, T. Contingent Valuation. A Handbook of Cultural Economics; Towse, R., Ed.; Edward Llgar: Northampton, MA, USA, 2003; p. 494. ISBN 184064-3382.

46. Vossler, C.A.; Holladay, J.S. Alternative value elicitation formats in contingent valuation: Mechanism design and convergent validity. J. Public Econ. 2018, 165, 133-145. [CrossRef]

47. Ready, R.C.; Buzby, J.C.; Hu, D. Differences between continuous and discrete contingent value estimates. Land Econ. 1996, 72, 397-411. [CrossRef]

48. Wang, H.; Mullahy, J. Willingness to pay for reducing fatal risk by improving air quality: A contingent valuation study in Chongqing, China. Sci. Total Environ. 2006, 367, 50-57. [CrossRef]

49. Carson, R.T.; Groves, T. Incentive and informational properties of preference questions. Environ. Resour. Econ. 2007, 37, 181-210. [CrossRef]

50. Carson, R.T.; Groves, T.; List, J.A. Consequentiality: A theoretical and experimental exploration of a single binary choice. J. Assoc. Environ. Resour. Econ. 2014, 1, 171-207. [CrossRef]

51. Haab, T.C.; McConnell, K.E. Valuing Environmental and Natural Resources: The Econometrics of Non-Market Valuation; Edward Elgar: Cheltenham, UK, 2002; ISBN 1843763885.

52. Suangka, K. Factors affecting elderly's decision to use public transportation: The application of structural equation model). Srinakharinwirot Univ. J. Sci. Technol. 2015, 7, 129-142.

53. Khamprasit, S. Factors Affecting Consumer Satisfaction with Nakhonchai Air Company Passenger Bus Services in Thailand. Available online: http:/ / ethesisarchive.library.tu.ac.th/thesis/2016/TU_2016_5802030576_5831_4228.pdf (accessed on 20 June 2018).

54. Madlee, A. Consumer Satisfaction on Bus Services of Weerakorn Company Limited Songkhla Province in the Route of HatYaiSungai Golok. Available online: http://graduate.hu.ac.th/thesis/2559/mpa/upwebariya.pdf (accessed on 20 June 2018).

55. Department of Land Transport. Transport Statistics Report. 2017. Available online: https://www.m-society.go.th/article_attach/ 19286/20656.pdf (accessed on 20 June 2018).

56. O'Garra, T.; Mourato, S.; Garrity, L.; Schmidt, P.; Beerenwinkel, A.; Altmann, M.; Hart, D.; Graesel, C.; Whitehouse, S. Is the public willing to pay for hydrogen buses? A comparative study of preferences in four cities. Energy Policy 2007, 35, 3630-3642. [CrossRef]

57. Annual Report of Bangkok 2020. Available online: http://www.bangkok.go.th/social (accessed on 10 April 2021).

58. All Choked Up: Thailand's Air Pollution. Available online: http://www.eiu.com/industry/article/1477870931/all-chokedupthailands-air-pollution/2019-04-04 (accessed on 10 July 2021).

59. Economic Costs of Bangkok Air Pollution Preliminarily Estimated to be at Least THB2.6 Billion. Available online: https: //kasikornresearch.com/en/analysis/k-econ/economy/Pages/z2955.aspx (accessed on 10 July 2021).

60. Sun, C.; Yuan, X.; Xu, M. The public perceptions and willingness to pay: From the perspective of the smog crisis in China. J. Clean. Prod. 2016, 112, 1635-1644. [CrossRef]

61. Liu, Z.; Hanley, N.; Campbell, D. Linking urban air pollution with residents' willingness to pay for greenspace: A choice experiment study in Beijing. J. Environ. Econ. Manag. 2020, 104, 102383. [CrossRef]

62. Cadle, S.H.; Croes, B.E.; Minassian, F.; Natarajan, M.; Tierney, E.J.; Lawson, D.R. Real-world vehicle emissions: A summary of the Thirteenth Coordinating Research Council on-road Vehicle Emissions Workshop. J. Air Waste Manag. Assoc. 2004, 54, 8-23. [CrossRef] [PubMed]

63. Yaduma, N.; Kortelainen, M.; Wossink, A. Estimating mortality and economic costs of particulate air pollution in developing countries: The case of Nigeria. Environ. Resour. Econ. 2013, 54, 361-387. [CrossRef]

64. Thorne, Z.; Hughes, L. Evaluating the effectiveness of electric vehicle subsidies in Canada. Procedia Comput. Sci. 2019, 155, 519-526. [CrossRef]

65. Santos, G.; Rembalski, S. Do electric vehicles need subsidies in the UK? Energy Policy 2021, 149, 111890. [CrossRef]

66. Venkatachalam, L. The contingent valuation method: A review. Environ. Impact Assess. Rev. 2004, 24, 89-124. [CrossRef] 
67. Freeman, A.M., III; Herriges, J.A.; Kling, C.L. The Measurement of Environmental and Resource Values: Theory and Methods; Routledge: Milton, UK, 2014.

68. Turner, R.K.; Pearce, D.W.; Bateman, I. Environmental Economics: An Elementary Introduction; Berghahn Books: New York, NY, USA, 1993. 